\title{
ELEMENTS OF BIOCLIMATOLOGICAL CHARACTERISTICS OF VRANJSKA SPA
}

\author{
VLADICA STEVANOVIĆ ${ }^{1 *}$ \\ ${ }^{1}$ Faculty of Natural Sciences and Mathematics, University of Priština, Kosovska Mitrovica, Serbia
}

\begin{abstract}
Bio-climatological analysis of Vranjska spa, based upon the equivalent temperatures (Teq) and Charles method (vapor weight), along with anthropo-climatic classification of Kruger, updated and adjusted, served as means of determining bio-climatological characteristics. Equivalent temperatures have been calculated for the period between 1985 and 2005, for the meteorological station Vranje, placed into six bio-climatological classes and three weather types. Representative weather types are cold $\left(5.0{ }^{\circ} \mathrm{C}<\mathrm{Teq}<22.0{ }^{\circ} \mathrm{C}\right)$, agreeable $\left(22.0{ }^{\circ} \mathrm{C}<\mathrm{Teq}<50.0^{\circ} \mathrm{C}\right)$ and overheated $\left(50.0{ }^{\circ} \mathrm{C}<\mathrm{Teq}<70.0{ }^{\circ} \mathrm{C}\right)$ with following classes: cold, algid, cool, agreeable, warm, humid and sultry.
\end{abstract}

Keywords: Equivalent temperature, Vapor weight, Bio-climatology, Vranjska spa, Anthropo-climatic classification, Weather types and classes.

\section{INTRODUCTION}

Bio-climatological influence is of great significance, regarded from the medical aspect of multiple effects the climate has on health and the choice of spa. According to Pecelj (2007), mission of ecological paradigm represents the establishing of harmony between a human being and nature through radical change of prevalent system of values and reforming of anthropocentric consciousness and ethic into eco-centric forms and contents of bio-climatological prospecting in eco tourism, thus representing a great opportunity.

When it comes to eco climatology (a symbiosis of climatology and ecology), we start from the scientific definition which further develops to interdisciplinarity, being a ground for understanding the functioning of the earth regions in climate system. All the changes in ecosystems are a significant feedback for climate system. The flow of energy and cycling of substance, water, chemical elements and gasses in ecosystems make climate determinants (Blazejczyk, 2004). Therefore, eco-climatological researches are conducted more often. Eco-climatology, as a scientific discipline, developed out of common interests of scientific researches of appearances and processes related to the atmosphere and biosphere.

According to Bonan (2002) eco-climatology is a combination of physical climatology, micro-meteorology, hydrology, pedology, plants physiology, biochemistry and biogeography of vegetation, made for the purpose of understanding the physicochemical and biological processes which influence climate, and vice versa. The importance of knowledge related to climatic and bioclimatic references of climate changes with which humanity faces today, is immeasurable (Pecelj, 2004). It is particularly important to point out the effect of global climate change to eco-climatic and

* Corresponding author: vladica.stevanovic@pr.ac.rs GEOGRAPHY, GEOSCIENCE AND ASTRONOMY bioclimatic values of spas, being important therapeutic, recreational and ecological destinations (Pecelj et al., 2010). Touristic marketing would be more complete, if it contained bioclimatological analyses and bio-prognosis (Matzarakis, 2006). Since tourism is one of the most perspective economic branches and climatic places ecologically most preserved in ecumene (Blanc, 1975), it is necessary to conduct climatological and bioclimatological analyses (Conrad, 1944). Accordingly, ecoclimatological analysis of Vranjska spa has been conducted. Vranjska spa is $12 \mathrm{~km}$ away from Vranje, in the direction of north-east, and $5 \mathrm{~km}$ away from the international highway E75. It is located in the east part of the basin of Vranje, in the valley of the river Banjštica, the right affluent of the South Morava. Vranjska Spa is at the elevation of $380 \mathrm{~m}$, surrounded with mountains Besna Kobila (1.922 m), Srpska Cuka (1.415 m), Veliki Pester $(1.946 \mathrm{~m})$ and Patarica $(1.806 \mathrm{~m})$, and therefore protected from strong winds, with temperate continental climate (Kostić, 1965). Vranjska Spa is famous for health tourism, due to the presence of thermal springs. The temperature of the water is $96{ }^{\circ} \mathrm{C}$ in old boreholes, whereas in new, under pressure the temperature is $110^{\circ} \mathrm{C}$. It is one of the hottest springs in Europe.

Bio-climatological observation of Vranjska spa is based on the combination of temperature and vapor pressure of water $(\mathrm{Et}=\mathrm{T}+2 \mathrm{e})$ which represents the base for determining the physiological feeling of warmth and weather types according to Kruger anthropo-climatic classification. Such a combination also includes, beside the temperature and vapor pressure of water, streaming of the air and air pressure, and it is known as the equivalent temperature. In bioclimatology, the importance of equivalent temperatures (temperature, water vapor pressure, air streaming and air pressure) is reflected through different feelings of warmth in healthy and sick people. In relation to equivalent temperatures there are three weather types (cold, agreeable and overheated) and six physiological feelings of warmth (from the feeling of cold, to the feeling of humidity). 
For the purpose of completing bio-climatological characteristics, beside equivalent temperatures, we further use the vapor weight (Charles method), based on the combination of temperature and relative humidity. The basis of this method is that heat is being transferred more easily in case of dry and windy weather, and more difficult in case of wet weather, without wind. Such unbearable heat is referred to as sultriness in climatology. Wind is also an important bioclimatic agent, since it influences on temperature characteristics, which further influences on bioclimatic effects on humans (Matzarakis, 2002). In dependence of air humidity and air pressure, people experience different feelings of warmth, although at the same temperature (Dukić, 1981).

Equivalent air temperature is practically the temperature of dry air, which would be a result of wet air water vapor condensation under constant pressure, the process which would release the heat spent during the previous process of evaporation. Latent heat, which is released during the processes of condensation and sublimation, is of high importance for equivalent temperatures. The transition of water into different states of aggregation is followed by the release or consumption of energy, thus provoking gigantic processes in geographical belt. To have 1 gram of water turned into gaseous state, it takes the energy of $2.533 * 10^{3} \mathrm{~J}$ (Milosavljević, 1985).

This bio-climatological analysis is based on the data from meteorological station in Vranje, for the period from 1981 to 2010 (Republički hidrometeorološki zavod, meteorološki godišnjaci). In reference to the connection of temperature, water vapor pressure and relative humidity, weather types and physiological feelings of warmth (equivalent temperatures) have been obtained and vapor weight (Table1, 2 and 3, Figure 1 and 2).

Table 1. Classification of physiological feelings of warmth and weather types.

\begin{tabular}{|c|c|c|}
\hline Teq $\left({ }^{\circ} \mathrm{C}\right)$ & $\begin{array}{c}\text { Physiological feeling of } \\
\text { warmth }\end{array}$ & Weather type \\
\hline$<5$ & Very cold & Cold type \\
$15-18$ & Cold & \\
$18-22$ & Algid & Agreeable type \\
\hline $22-30$ & Cool & \\
$30-40$ & Agreeable & Overheated type \\
$40-50$ & Warm & \\
\hline $50-58$ & Humid & Sultry \\
$58-70$ & Very sultry & \\
$>70$ & &
\end{tabular}

\section{PSYSIOLOGICAL FEELING OF WARMTH AND WEATHER TYPES IN VRANJSKA SPA}

Cold weather type $\left(5.0{ }^{\circ} \mathrm{C}<\right.$ Teq $\left.<22.0{ }^{\circ} \mathrm{C}\right)$ is present in January, February and March. Physiological feeling of warmth classified as cold $\left(\mathrm{Teq}=5.0-18.0^{\circ} \mathrm{C}\right)$ occurs in January $(\mathrm{Teq}=$ $\left.9.6{ }^{\circ} \mathrm{C}\right)$ and in February $\left(\right.$ Teq $\left.=11.9{ }^{\circ} \mathrm{C}\right)$. Physiological feeling of warmth for the algid weather type $\left(\mathrm{Teq}=18.0-22.0{ }^{\circ} \mathrm{C}\right.$ ) is characteristic of March $\left(\mathrm{Teq}=18.3{ }^{\circ} \mathrm{C}\right)$. Physiological feeling of warmth for the type very cold (Teq $<5.0^{\circ} \mathrm{C}$ ) is not present. Winter is the season with the lowest level of accumulated latent heat. January, February as well as the most of winter, are characterized by the dominant influence of middle-European anticyclone which brings dry and cloudy weather. It is the period of inverse manifestations of primarily radiation type, which is the consequence of both weather and local conditions.

Agreeable weather type $\left(22.0{ }^{\circ} \mathrm{C}<\right.$ Teq $\left.<50.0{ }^{\circ} \mathrm{C}\right)$ occurs in April, May, June, September, October, November and December. Physiological feeling of warmth which is referred to as cool, according to the classification $\left(\mathrm{Teq}=22.0-30.0^{\circ} \mathrm{C}\right)$ is present in April $\left(\mathrm{Teq}=28.1{ }^{\circ} \mathrm{C}\right)$ and December $\left(\mathrm{Teq}=22.5^{\circ} \mathrm{C}\right)$. The class agreeable $\left(\mathrm{Teq}=30.0-40.0{ }^{\circ} \mathrm{C}\right.$ ) is present in May $\left(\right.$ Teq $\left.=39.8^{\circ} \mathrm{C}\right)$, October $\left(\right.$ Teq $\left.=32.9^{\circ} \mathrm{C}\right)$ and in November $($ Teq $\left.=32.2{ }^{\circ} \mathrm{C}\right)$. The class warm $\left(\mathrm{Teq}=40.0-50.0^{\circ} \mathrm{C}\right)$ is present in June $\left(\mathrm{Teq}=49.1{ }^{\circ} \mathrm{C}\right)$ and in September $\left(\mathrm{Teq}=43.3^{\circ} \mathrm{C}\right)$. It is the period of the effects of anticyclone activities, and favorable bioclimatological characteristics. The level of accumulated latent heat is then the highest, which is the consequence of thermal characteristics, whose annual cycle follows the water vapor pressure. Overheated weather type $\left(50.0{ }^{\circ} \mathrm{C}<\mathrm{Teq}<70.0{ }^{\circ} \mathrm{C}\right)$ occurs in July (Teq $\left.=52.9{ }^{\circ} \mathrm{C}\right)$ and in August $\left(\right.$ Teq $=52.0^{\circ} \mathrm{C}$ ) within the class humid $\left(\mathrm{Teq}=50.0-58.0^{\circ} \mathrm{C}\right)$. The reason lies in antropogeographic influence and in relief which limits the intense streaming of air. There is no occurrence of the classes sultry and very sultry.

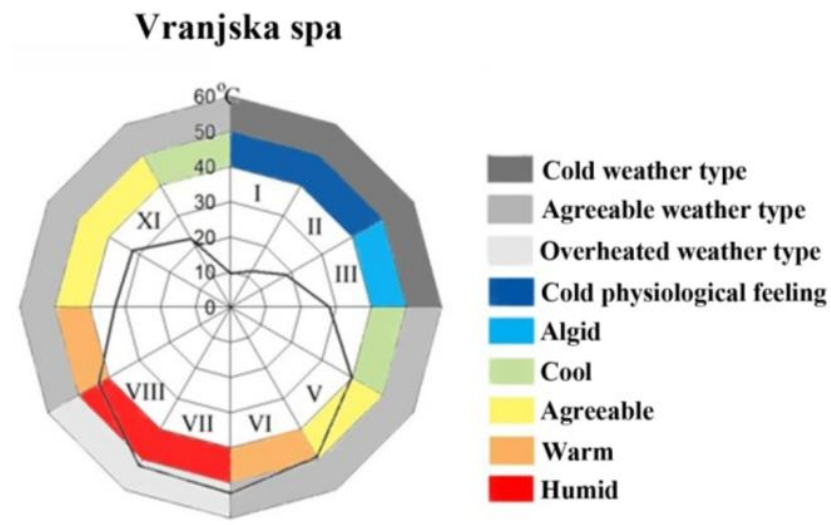

Figure 1. Average monthly equivalent temperatures in Vranjska spa.

\section{ANALYSIS OF THE DEGREE OF AGREEABILITY BY CHARLES' METHOD}

German climatologist Charles in his work: „Humidity comfort zone and limiting humidity zones“, published in 1950 (Charles, 1950), experimentally defined boundary values of temperature in the function of relative humidity in the absence of 
wind, based on which, the degree of physiological disagreeability

in hotter and colder part of the year can be presented.

Table 2. Annual cycle of equivalent temperatures (Vranjska spa 1981-2010) in ${ }^{\circ} \mathrm{C}$.

\begin{tabular}{|c|c|c|c|c|c|c|c|c|c|c|c|c|}
\hline Teq $\left({ }^{\circ} \mathrm{C}\right)$ & I & II & III & IV & V & VI & VII & VIII & IX & X & XI & XII \\
\hline Vranjska Spa & 9.6 & 11.9 & 18.3 & 28.1 & 39.8 & 49.1 & 52.9 & 52.0 & 43.3 & 32.9 & 32.2 & 22.5 \\
\hline
\end{tabular}

Table 3. Boundary values of temperature and relative humidity for the determining the degree of disagreeability according to Charles.

\begin{tabular}{|cccccccccccccccc|}
\hline \multicolumn{110}{|c|}{ Upper boundary values of temperature } \\
\hline $\mathrm{f}(\%)$ & 100 & 95 & 90 & 85 & 80 & 75 & 70 & 65 & 60 & 55 & 50 & 45 & 40 & 35 & 30 \\
$\mathrm{~Tb} 2\left({ }^{\circ} \mathrm{C}\right)$ & 15.5 & 17.3 & 18.2 & 19.1 & 20.1 & 21.1 & 22.2 & 23.4 & 24.8 & 25.2 & 28 & 30.1 & 32.2 & 34.8 & 35.5 \\
\hline \multicolumn{110}{c|}{ Lower boundary values of temperature } \\
\hline $\mathrm{f}(\%)$ & 95 & 90 & 85 & 80 & 75 & 70 & 65 & 60 & 55 & 50 & 45 & 40 & 35 \\
$\mathrm{~Tb} 1\left({ }^{\circ} \mathrm{C}\right)$ & 3.8 & 3.5 & 2.8 & 2.2 & 1.8 & 1.5 & 0.5 & 0 & -0.3 & -0.5 & -1.5 & -2.5 & -2.8 \\
\hline
\end{tabular}

Two formulas have been presented for the calculating of boundary values of temperature for colder ( $\mathrm{Tb} 1)$ and hotter part of the year $(\mathrm{Tb} 2)$, respectively:

$$
\begin{aligned}
& \text { Tb1 }=\left(-0.0003 \cdot f^{2}\right)+(0.1497 \cdot f)-7.7133, \\
& \text { Tb2 }=(-17.089 \cdot \ln (f))+94.979,
\end{aligned}
$$

where $\mathrm{Tb}$ is boundary value of temperature $\left({ }^{\circ} \mathrm{C}\right)$ and $\mathrm{f}$ is relative humidity $(\%)$.

These boundary values of temperature in dependence of relative humidity represent the value based on which we determine bio-climatological agreeability or disagreeability. In Table 3 (lower boundary value of temperature) for each value of relative humidity, there is a boundary value of air temperature, under which human body feels physiological disagreeability, in the absence of wind. Index of winter disagreeability according to Charles refers only to values of relative humidity above $40 \%$ and it is sensitive to the temperature range between $-6^{\circ} \mathrm{C}$ and 5 ${ }^{\circ} \mathrm{C}$. Beyond the range, index shows extreme values of classification, representing physiological comfort at the temperatures above $5^{\circ} \mathrm{C}$ and extremely cold disagreeability at the temperatures below $-6^{\circ} \mathrm{C}$.

In Table 3 (upper boundary value of temperature) for each value of relative humidity, there is a boundary value of air temperature, above which human body feels disagreeable in the absence of wind. Index of winter disagreeability, according to Charles, refers only to the values of relative humidity above $30 \%$ and it is sensitive to the temperature range between $17^{\circ} \mathrm{C}$ and 39 ${ }^{\circ} \mathrm{C}$. Beyond the range, index shows extreme values of classification, representing physiological comfort at the temperatures below $17^{\circ} \mathrm{C}$ and extremely hot disagreeability at the temperatures above $39^{\circ} \mathrm{C}$.

By analyzing the average monthly values of temperature and relative humidity for the period from 1981-2010, it is perceived that the degree of disagreeability in the spa occurs only in the colder part of the year, in January and February, whereas in hotter part of the year there is no disagreeability, except in the case of sultriness in July and August.

Charles' method was represented by the formula, with the help of which boundary values of temperature are determined, in the function of relative humidity, without the influence of wind. The degree of physiological disagreeability is shown for colder (Table 1) and hotter part of the year (Table 2), pointing to a different bioclimatic situation in comparison with former simplified graphs we were using. According to Charlaues' method, the degree of disagreeability occurs in colder part of the year (January and February), whereas there is no disagreeability in hotter part of the year, except in case of sultriness in July and August.

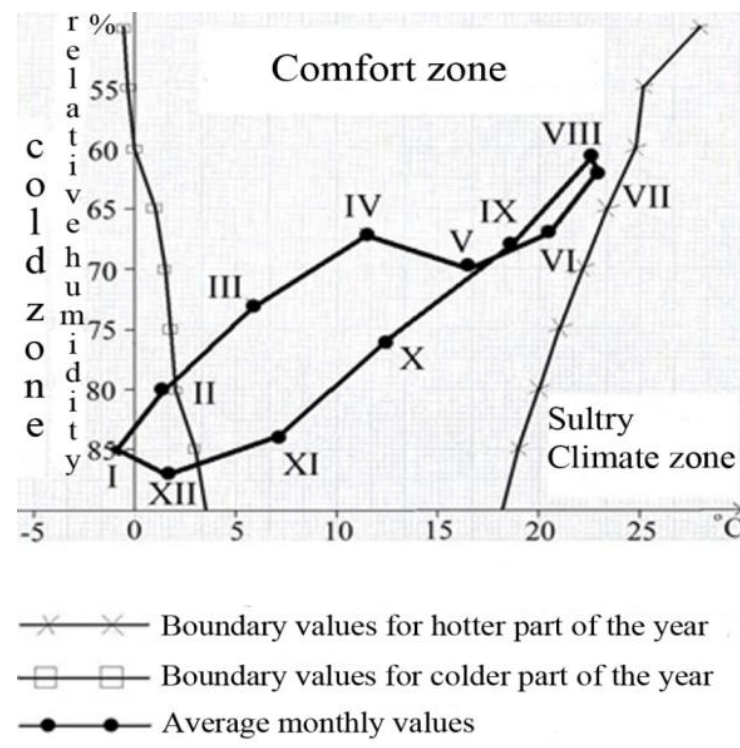

Figure 2. The average occurrence of sultriness in Vranjska spa.

\section{CONCLUSION}

Agreeable weather type is predominant and it lasts for seven months (April, May, June, September, October, November and December). The class Agreeable dominates in the middle of spring in May (Teq $=39.8{ }^{\circ} \mathrm{C}$ ), in October (Teq $=32.9{ }^{\circ} \mathrm{C}$ ) and in November $\left(\mathrm{Teq}=32.2{ }^{\circ} \mathrm{C}\right.$ ). Cold weather type lasts for three month with dominant classes of cold and algid. The class which 
is referred to as humid during July and August implicates the presence of Overheated weather type.

By using Charles' method for the determining of sultriness, through combination of relative humidity and temperature, there is a visible curve in vapor weight, being pretty distant from the boundary between the sultry climate zone and comfort zone (agreeable feelings). Thus, there is no real sultriness, even beside high summer temperatures, the reason being in low relative humidity during the summer months. Of course, based on average monthly temperatures, sultry days are not excluded (which is regarded relatively within the very procedure, i.e. the method).

From the point of bioclimatology, in respect to equivalent temperatures and vapor weight which influence the physiological effects of climate, Vranjska spa and its surrounding area is considered to be a beneficial area, which can be further improved in accordance with physico-geographical and anthropogeographical predispositions, and valorized adequately. It is a matter of serious considerations, belonging to the area of medical policy, touristic plans and interests, as well as contemporary ecological demands.

\section{REFERENCES}

Blanc de, J. 1975. Man in the cold. Ch.C. Thomas Publ., Springfield.

Blazejczyk, K. 2004. Assessment of radiation balance in man in various meteorological and geographical conditions, Geographia Polonica, 77(1), pp. 63-76.
Bonan, G. 2002. Ecological Climatology, Concepts and applications. Cambridge: University Press.

Charles, K. 1950. Humidity comfort zone and limiting humidity zones. Erdkunde, v.4, pp. 188-201.

Conrad, V. 1944. Methods in Climatology, Harvard University Press, Cambridge, Massachusetts, p.228.

Dukić, D. 1981. Klimatologija. Beograd: Naučna knjiga.

Kostić, M. 1965. Vranjska Banja. Leskovački zbornik, Knj. V, str. 85-109; Narodni muzej Leskovac, Leskovac.

Matzarakis, A. 2006. Weather- and climate-related information for tourism. Tourism and Hospitality Planning and Development, 3(2), pp. 99-115. doi:10.1080/14790530600938279

Matzarakis, A. 2002. Radiation and Termal Comfort, Proceedings of the 6ht Hellenic Conference in Meteorology, Climatology and Atmospheric Physics, Ioannina, Greece, pp. 739-744.

Meteorološki godišnjaci, 1981-2010. Republičkiv hidrometeorološki zavod, Beograd.

Milosavljević, M. 1985. Klimatologija. Beograd: Naučna knjiga.

Pecelj R. M., Pecelj M., Mandic D., Pecelj J., Vujadinović S., Secerov V., Sabić D., Gajić M., \& Milinčić M. 2010. Bioclimatic Assessment of Weather Condition for Recreation in Health Resorts, Proceedings book of 8th WSEAS International Conference on Enviroment, Ecosystems and Development, Athens, Greece, pp. 211-214.

Pecelj, M., Milincic, M., \& Pecelj, M. 2007. Bioclimatology and ecoclimatology prospecting: Right out development. Glasnik srpskog geografskog društva, 87(2), pp. 199-210. doi:10.2298/gsgd0702199p

Pecelj, R. M. 2004. Bioklimatska istraživanja, metodologija i multidisciplinarnost, Radovi, Filozofski fakultet, Istočno Sarajevo. 